\title{
Recent advances in understanding of the pathogenesis of
}

\section{ANCA-associated vasculitis [version 1; peer review: 2}

\section{approved]}

\author{
Maria Prendecki (iD, Charles D. Pusey \\ Department of Medicine, Imperial College London, Hammersmith Campus, Du Cane Road, London, W12 0NN, UK
}

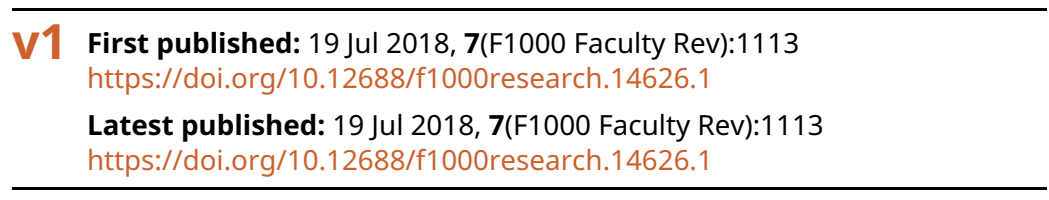

\section{Abstract}

Anti-neutrophil cytoplasm antibody (ANCA)-associated vasculitides (AAV) are rare systemic autoimmune diseases characterised by inflammation of small blood vessels. Recent developments have been made in our understanding of the pathogenesis of these diseases, including the pathogenic role of ANCA, neutrophils and monocytes as mediators of injury, dysregulation of the complement system, and the role of $T$ and B cells. Current treatment strategies for AAV are based on broad immunosuppression, which may have significant side effects. Advances in understanding of the pathogenesis of disease have led to the identification of new therapeutic targets which may lead to treatment protocols with less-toxic side effects. The aim of this review is to summarise current information and recent advances in understanding of the pathogenesis of AAV.

Keywords

ANCA, Vasculitis

\section{Open Peer Review}

Approval Status

1

2

\section{version 1}

19 Jul 2018

Faculty Reviews are review articles written by the prestigious Members of Faculty Opinions. The articles are commissioned and peer reviewed before publication to ensure that the final, published version is comprehensive and accessible. The reviewers who approved the final version are listed with their names and affiliations.

\footnotetext{
1. Minghui Zhao, Peking University First Hospital, Beijing, China

2. Augusto Vaglio, University Hospital of Parma, Parma, Italy

Any comments on the article can be found at the end of the article.
} 
Corresponding author: Maria Prendecki (m.prendecki@imperial.ac.uk)

Author roles: Prendecki M: Writing - Original Draft Preparation; Pusey CD: Writing - Review \& Editing

Competing interests: No competing interests were disclosed.

Grant information: We acknowledge support from the NIHR Imperial Biomedical Research Centre.

The funders had no role in study design, data collection and analysis, decision to publish, or preparation of the manuscript.

Copyright: $\odot 2018$ Prendecki M and Pusey CD. This is an open access article distributed under the terms of the Creative Commons

Attribution License, which permits unrestricted use, distribution, and reproduction in any medium, provided the original work is properly cited.

How to cite this article: Prendecki $M$ and Pusey CD. Recent advances in understanding of the pathogenesis of ANCA-associated vasculitis [version 1; peer review: 2 approved] F1000Research 2018, 7(F1000 Faculty Rev):1113

https://doi.org/10.12688/f1000research.14626.1

First published: 19 Jul 2018, 7(F1000 Faculty Rev):1113 https://doi.org/10.12688/f1000research.14626.1 


\section{Introduction and background}

The anti-neutrophil cytoplasm antibody (ANCA)-associated vasculitides (AAV) are a group of systemic autoimmune diseases characterised by inflammation of small blood vessels with multi-organ involvement, including the kidney, lung, nerves, gut, and ear, nose, and throat (ENT). Until 1979, it was assumed that rapidly progressive glomerulonephritis (RPGN) was caused by circulating immune complexes or anti-glomerular basement membrane (anti-GBM) antibodies. However, Stilmant et al. observed that many cases had no evidence of glomerular deposition of complement or immunoglobulin and were pauci-immune ${ }^{1}$. Subsequently, antibody binding to neutrophil cytoplasm was shown by using serum from patients with crescentic glomerulonephritis for indirect immunofluorescence ${ }^{2}$. The two main target antigens of ANCA were then identified as proteinase-3 (PR3) and myeloperoxidase (MPO), which are present in the granules of neutrophils and lysosomes of monocytes $^{3-5}$. There are differing clinical syndromes associated with ANCA: granulomatosis with polyangiitis (GPA), microscopic polyangiitis (MPA), eosinophilic GPA (EGPA), and renal limited vasculitis. Around $10 \%$ of patients are ANCA negative ${ }^{6}$. The aim of this review is to provide an overview of the current information and recent advances in understanding of the pathogenesis of AAV focussing on MPA and GPA rather than EGPA.

AAV is uncommon; its incidence in Europe is reported to be 13 to 20 cases per million ${ }^{7}$. There is a slight male preponderance, and incidence increases with age, although peak incidence has been reported variously as 55 to 64,65 to 74 , and more than 75 years $^{7-9}$. AAV is rarer in non-Caucasian or nonAsian populations, and there are differences in the incidence of different clinical phenotypes between populations. When a Japanese and UK population were directly compared, the overall incidence of AAV was similar but GPA was much less common in $\operatorname{Japan}^{10}$. There is certainly a genetic basis for AAV, and this may explain some of the population differences. Two large genome-wide association studies showed an association between AAV and genetic factors, and there was a stronger genetic association with ANCA specificity than clinical syndrome, suggesting that MPO-ANCA and PR3-ANCA may be defining differing diseases. In anti-PR3 AAV, there were associations with $H L A-D P, P R T N 3$ (the gene encoding proteinase-3), and SERPINA1 (the gene encoding a1-antitrypsin, a circulating inhibitor of PR3); anti-MPO AAV was associated mainly with $H L A-D Q$ polymorphisms ${ }^{11,12}$. There are reports of an association between $H L A-D R B 1 * 15$ and PR3-ANCA in African-Americans, and $H L A \quad D P B 1 * 0401$ has also been associated with PR3ANCA disease ${ }^{13,14}$. Several studies have shown an association with a single-nucleotide polymorphism (SNP) in PTPN22 (the gene encoding a lymphoid-specific phosphatase which is involved in T-cell activation) and GPA, although whether this SNP is also associated with MPA is less clear ${ }^{15,16}$.

There are several reported environmental associations with AAV. Infection may precede disease relapse and nasal carriage of staphylococci correlates with disease relapse in patients with anti-PR3 AAV and ENT disease ${ }^{17}$. A mechanism of molecular mimicry whereby an immune response against microbial antigens cross-reacts with self tissue has been proposed ${ }^{18}$. An atypical ANCA, anti-human lysosome-associated membrane protein2 (anti-LAMP-2) antibody, was first identified in patients with pauci-immune glomerulonephritis (GN) in 1995 and has 100\% sequence homology with FimH, a bacterial adhesion protein on Gram-negative bacteria. Rats immunised with FimH develop GN and antibodies which react to human and rat LAMP-2 ${ }^{18}$. However, the clinical association has been reproduced in some but not other laboratories ${ }^{19,20}$. An alternative proposal involves complementary peptides of the auto-antigen. Patients with anti-PR3 AAV have been shown to have circulating antibodies to both PR3 and anti-sense complementary PR3 peptides (cPr3), suggesting that an initial immune response may be against the anti-sense peptide leading to the development of anti-idiotype antibodies which recognise PR ${ }^{21}$.

Other environmental risk factors identified include silica, heavy metal exposure and drugs which can induce ANCA, including propylthiouracil, hydralazine, and levamisole-contaminated cocaine $^{22-24}$

\section{Pathogenicity of ANCA}

ANCA have been shown to be pathogenic in several clinical and pre-clinical studies. There is a reported case of maternalfoetal transfer of anti-MPO ANCA resulting in neonatal renal disease and pulmonary haemorrhage shortly after birth ${ }^{25}$. Levels of ANCA have been shown to correlate with disease activity in some but not all case series with better correlation in patients with renal disease ${ }^{26}$. Removal of antibodies with plasma exchange has been shown to improve prognosis in severe $\mathrm{AAV}^{27}$, and depletion of $\mathrm{B}$ cells with rituximab has been shown to be effective in induction and maintenance of remission ${ }^{28-30}$.

Some of the best evidence for the pathogenesis of ANCA comes from a passive transfer model of anti-MPO AAV. MPO-deficient mice are immunised with mouse MPO and develop hightitre anti-MPO antibodies. Transfer of these antibodies into wild-type or Rag2 mice (which lack lymphocytes) results in the mice developing severe vasculitis with crescentic GN and pulmonary haemorrhage, demonstrating that MPO-ANCA alone are sufficient to induce disease ${ }^{31}$. Neutrophils were shown to have an essential role in disease pathogenesis in this model; depletion of neutrophils prior to transfer of antibodies prevented the development of disease ${ }^{32}$. ANCA have also been shown to be pathogenic in an autoimmune rat model of AAV, experimental autoimmune vasculitis in the susceptible WKY rat strain. Rats are immunised with human MPO in complete Freund's adjuvant and also receive two doses of intraperitoneal pertussis toxin as an immune adjuvant. Animals develop polyclonal anti-MPO antibodies with pauci-immune vasculitis and pulmonary haemorrhage. Intra-vital imaging in this model showed increased leucocyte adhesion and transmigration at the endothelium in response to CXCL1, and this could also be observed in healthy animals following infusion of anti-MPO IgG isolated from rats with disease, supporting a role for the pathogenicity of $\mathrm{ANCA}^{33}$. The pathogenic role of PR3-ANCA is less well defined and this is owing, at least in part, to the difficulty in developing animal models of anti-PR3 AAV. An attempt to create a passive transfer model analogous to the one using anti-MPO 
antibodies resulted in no features of vasculitis and only a mild inflammatory response to tumour necrosis factor (TNF) in the $\operatorname{skin}^{34}$. This is potentially due to a lack of PR3 expression on the surface of unstimulated mouse neutrophils and a lesser degree of sequence homology between mouse and human PR3 than there is for $\mathrm{MPO}^{35}$.

Despite evidence for the pathogenicity of ANCA, the relationship between ANCA and active vasculitis is complex and ANCA are not always pathogenic. ANCA can persist in remission, can recur without evidence of clinical relapse, and have been identified in healthy individuals. Natural anti-MPO antibodies are of lower avidity and titre than are antibodies from patients with $\mathrm{AAV}^{36}$. The IgG subclass of ANCA may also be important. In vitro, IgG3-ANCA has been shown to be more effective than other IgG subclasses at activating neutrophils, although in other clinical studies the IgG subclass of ANCA did not correlate with disease severity ${ }^{37,38}$. Epitope mapping to identify the pathogenic epitopes of both PR3 and MPO have been carried out. One study using epitope excision and mass spectrometry identified a linear epitope on MPO at residue 447-459 that was limited to patients with disease; interestingly, when the three-dimensional structure of MPO was visualised, this epitope was close to epitopes seen in individuals with natural antibodies, leading the authors to suggest that pathogenic ANCA arise by a process of epitope spreading. In this study, IgG purified from patients with ANCAnegative vasculitis was able to bind to an MPO epitope, and it was suggested that competition for binding in immunoassays by a fragment of caeruloplasmin may be why ANCA cannot be detected in these patients ${ }^{39}$.

\section{ANCA-induced activation of neutrophils and monocytes}

The ability of ANCA to bind to and activate neutrophils causing degranulation and production of reactive oxygen species (ROS) was first shown nearly 30 years $\mathrm{ago}^{40}$. Since then, several in vitro studies have shown that neutrophils which have been primed with TNF $\alpha$, lipopolysaccharide (LPS), or complement (C5a) undergo activation and degranulation and mediate endothelial cell damage when stimulated with MPO or PR3-ANCA ${ }^{41,42}$. ANCA binding to neutrophils has also been shown to activate intracellular signalling pathways leading to altered adhesion molecule expression and conformational changes which promote neutrophil adhesion and transmigration at the vascular endothelium ${ }^{43}$. Both the ANCA antigen-binding site and binding to $\mathrm{Fc} \gamma$ receptors on the surface of primed neutrophils and monocytes have been identified as mechanisms by which ANCA activates these cells.

ANCA have also been shown to be mediators of NETosis, a form of neutrophil cell death with release of neutrophil extracellular traps (NETs). NETs have a DNA backbone with a variety of pro-inflammatory proteins, including histones, high-mobility group box 1 (HMGB-1), neutrophil elastase, calprotectin, MPO, and PR3 ${ }^{44}$. NETs have been shown to be present at sites of tissue damage in $\mathrm{AAV}$, and patients also have increased levels of NETs in the circulation ${ }^{45}$. NETs may play a pathogenic role in AAV; they can cause activation of dendritic cells and autoreactive $\mathrm{B}$ cells, endothelial damage, and complement activation $^{46,47}$. NETs may also play a role in the loss of tolerance to ANCA antigens; one study has shown that dendritic cells activated by NETs induce loss of tolerance to both MPO and $\mathrm{PR}^{48}$. Neutrophils from patients with AAV undergo more spontaneous NETosis than those from healthy controls, but ANCA can also induce this process. The exact mechanism by which ANCA induce NETosis is unclear but is thought to require binding of both Fc $\gamma$ receptors and the ANCA target antigen on the cell surface ${ }^{49}$.

Although many studies have focussed on neutrophils and their interactions with ANCA in the pathogenesis of disease, monocytes may also play a role in mediating AAV. Monocytes express ANCA antigens, and stimulation of monocytes in vitro with ANCA leads to cytokine production and generation of $\operatorname{ROS}^{50,51}$. Monocytes from patients with AAV have been shown to express higher levels of CD14, the LPS receptor, than monocytes from patients in remission or healthy controls, suggesting an increased cell activation state in patients with $\mathrm{AAV}^{52}$. Circulating monocytes from patients with active AAV have also been shown to express higher levels of cell surface markers which are essential for interaction between leucocytes and the endothelium ${ }^{53}$. Recent studies have shown that monocytes and macrophages are the predominant cells in glomeruli in renal biopsies from patients with $\mathrm{AAV}^{54,55}$. In one study using the passive transfer model of mouse anti-MPO AAV, depleting monocytes decreased glomerular crescent formation but had no effect on urinary abnormalities $^{56}$.

\section{Complement and AAV}

There is increasing evidence for a role for complement in the pathogenesis of AAV. In the antibody transfer model of mouse anti-MPO AAV, mice deficient in C5 or those depleted of complement by pre-treatment with cobra venom did not develop disease. C4-deficient mice were not protected, suggesting a role for the alternative rather than the classic pathway ${ }^{57}$. Mice deficient in $\mathrm{C} 5 \mathrm{aR}$ are protected from disease, and mice with knock-in of the human C5a receptor treated with an antagonist of human C5aR (CCX168; avacopan) showed decreased disease severity ${ }^{58,59}$. There is also evidence for a role for complement from in vitro studies; C5a can prime neutrophils to respond to stimulation by ANCA, and this may be due to its actions at the $\mathrm{C}_{5} \mathrm{aR}^{42}$. The interaction of $\mathrm{C} 5 \mathrm{a}$ with its other receptor, C5L2, is more complex, and some studies report that it has a proinflammatory role in vitro but knockout of C5L2 resulted in more-severe disease in mouse anti-MPO $\mathrm{AAV}^{59,60}$. It has also been shown that both ANCA-stimulated neutrophils and NETs can activate the alternative pathway of the complement system, leading to a positive feedback loop ${ }^{47,57}$. There is evidence of complement deposition, such as $\mathrm{C} 3 \mathrm{~d}$ and factor $\mathrm{B}$, at sites of tissue inflammation in patients with AAV and kidney deposition of $\mathrm{Bb}$ (a marker of activation of the alternative pathway) correlated with pathological severity of disease ${ }^{61}$. Plasma levels of C3a, C5a, soluble C5b-9, and Bb were higher in patients with active $\mathrm{AAV}$ than in those in remission ${ }^{62,63}$. In one study, patients with lower circulating C3 levels were shown to have poorer outcomes in terms of both patient and renal survival ${ }^{64}$. Blockade of C5 cleavage with eculizumab has been reported as treatment for $\mathrm{AAV}$ in one case report. It was used as 
add-on therapy to cyclophosphamide with good renal recovery, although unfortunately the patient developed non-Hodgkin lymphoma, thought to be unrelated to the eculizumab, and died from sepsis following chemotherapy ${ }^{65}$. A recently published phase II trial has shown that avacopan was effective in replacing high-dose glucocorticoids for induction of remission when added to cyclophosphamide or rituximab ${ }^{66}$. A phase III trial of this treatment approach is currently recruiting (ADVOCATE, ClinicalTrials.gov Identifier: NCT02994927).

\section{$B$ cells and AAV}

$\mathrm{B}$ cells have a central role in AAV in that they produce ANCA, and levels of activated B cells have been shown to correlate with disease activity ${ }^{67}$. Depletion of $\mathrm{B}$ cells with rituximab has been shown to be effective in inducing and maintaining disease remission ${ }^{28,29}$. The return of $\mathrm{B}$ cells after rituximab may predict relapse of $\mathrm{AAV}$, and it has been shown that following induction of remission with rituximab and cyclophosphamide, the return of $\mathrm{B}$ cells has a high negative predictive value for relapse but a poor positive predictive value ${ }^{68,69}$. It may be that the phenotype of the repopulating B cells is important in predicting relapse, and one study suggested that those who repopulate with a low percentage of $\mathrm{CD}^{+} \mathrm{B}$ cells have a shorter time to relapse $^{70}$. Several studies have shown differences in B-cell subsets between patients with AAV and healthy controls. One study reported a memory B-cell subset with higher CD19 expression in patients with AAV, suggesting that these may represent autoreactive B cells ${ }^{71}$. Regulatory B $\left(\mathrm{B}_{\text {reg }}\right)$ cells skew T-cell differentiation towards regulatory $\mathrm{T}\left(\mathrm{T}_{\mathrm{reg}}\right)$ cells and away from $\mathrm{T}$ helper $1\left(\mathrm{~T}_{\mathrm{H} 1}\right)$ and $\mathrm{T}_{\mathrm{H} 17}$ phenotypes and decrease $\mathrm{B}$ cells which are producing $\mathrm{ANCA}^{72}$. Several studies have shown decreased $\mathrm{B}_{\text {reg }}$ cells in patients with AAV as defined by cell surface markers such as $\mathrm{CD} 5, \mathrm{CD} 24$, and $\mathrm{CD} 38^{73,74}$. In vitro, neutrophils stimulated with ANCA release B-cell survival factors such as B lymphocyte stimulator (BLyS) and a proliferation-inducing ligand (APRIL). In one study, incubating B cells with supernatant from ANCA-stimulated neutrophils or with recombinant BLyS resulted in increased B-cell survival ${ }^{75}$. Several studies have reported higher levels of BLyS in patients with AAV, and some have shown that levels correlated with disease activity and ANCA titre and decreased following treatment ${ }^{76,77}$. Following rituximab treatment, serum BLyS levels have been shown to increase both in patients with AAV and in patients with other auto-immune diseases ${ }^{75,78}$. One study has shown that a SNP in BLyS predicted which patients were more likely to relapse following rituximab and had earlier return of B cells after treatment. The authors suggest that this SNP may result in higher baseline BLyS or increase in BLyS after B-cell depletion ${ }^{79}$. This may suggest a potential role for targeting BLyS as maintenance treatment of AAV following induction treatment with rituximab. A phase III trial which added anti-BLyS treatment with belimumab to azathioprine and steroids for maintenance of remission did not show any reduction in risk of relapse; however, in the subgroup of patients who received rituximab as an induction agent, belimumab did reduce relapse rate, although this was not significant ${ }^{80}$.

\section{T-cell immunity and AAV}

$\mathrm{T}$ cells are present in glomeruli and the tubulointerstitium in renal biopsy tissue from patients with AAV, suggesting that T-cell responses are pathogenic. Studies have shown that patients with AAV have defective $\mathrm{T}_{\text {reg }}$ cell suppressive function ${ }^{81}$; one study has also shown increased frequency of a CD4 ${ }^{+} \mathrm{T}$-cell subset that is resistant to the suppressor effects of $\mathrm{T}_{\text {reg }}$ cells ${ }^{82}$. In a small group of patients, anti-thymocyte globulin was used as a successful treatment for refractory GPA ${ }^{83}$. Additionally, differential $T_{H}$ cell polarisation has been described in AAV, such that patients with active and systemic disease are more likely to have a $\mathrm{T}_{\mathrm{H} 2}$ response $^{84}$.

In the mouse passive transfer model of anti-MPO AAV, $\mathrm{CD} 4^{+} \mathrm{T}$ cells have been used to transfer disease, demonstrating a role for $\mathrm{T}$ cells in pathogenesis. Mice pre-immunised with $\mathrm{CD}^{+} \mathrm{T}$ cells from MPO-immunised, B-cell-deficient, MPO-deficient mice developed greater severity of GN after induction of disease with MPO-ANCA compared with mice immunised with OVAsensitised $\mathrm{CD}^{+}{ }^{+}$cells ${ }^{85}$. In a model of anti-MPO AAV in which mice are immunised with MPO followed by a subnephritogenic dose of anti-GBM globulin, depletion of $\mathrm{CD}^{+}$cells decreased disease severity with no effect on ANCA titres ${ }^{86}$. This model of disease has been used to identify pathogenic epitopes for both $\mathrm{CD}^{+}$and $\mathrm{CD} 8^{+} \mathrm{T}$ cells, and these epitopes have been used to induce disease ${ }^{87,88}$.

The $\mathrm{T}_{\mathrm{H} 17}$ axis may also be involved in the development of ANCA; serum interleukin-23 (IL-23) and IL-17 are raised in the serum of patients with acute AAV, and in one study IL-23 levels correlated with disease activity ${ }^{89}$. IL-23 induces T-cell differentiation into the $\mathrm{T}_{\mathrm{H} 17}$ subset and enhances the production of IL-17 from these cells. Stimulation of neutrophils by ANCA has been shown to induce the production of IL-1790, and in one study IL-17-deficient mice were protected from MPOANCA-induced disease ${ }^{91}$.

\section{Granuloma formation}

Granulomatous disease is frequently seen in isolated and systemic GPA. Early granuloma formation is typified by activated neutrophils forming micro-abscesses and only scattered multinucleated giant cells. Later granulomas consist of a central necrotic area with multinucleated giant cells at the margin and surrounding dendritic cells, T lymphocytes, B lymphocytes, and plasma cells forming a follicular structure of ectopic lymphoid tissue ${ }^{92,93}$. The mechanisms initiating granuloma formation have not been fully identified, but there is some evidence that granulomatous inflammation is being driven by $\mathrm{T}$ cells producing $\mathrm{T}_{\mathrm{H} 1}$ cytokines $^{94}$. It has also been shown that APRIL and BLyS are present in granulomas along with activated B cells, leading some authors to suggest that close association of B cells with PR3-positive cells within granulomas could lead to initiation or maintenance of anti-PR3 responses ${ }^{95}$. In an in vivo model of xenografted nasal mucosa from patients with GPA to mice, tissue damage was shown to be mediated by fibroblasts ${ }^{96}$.

\section{Conclusions}

The pathogenesis of AAV is complex and remains incompletely understood. Recent advances have been made in our understanding of the mechanisms of both the development of auto-immunity and inflammation leading to tissue damage. Our understanding of the generation of the auto-immune response is incomplete but may well involve molecular mimicry and dysregulation of both $\mathrm{B}$ and $\mathrm{T}$ cells. There is substantial evidence 
for the pathogenicity of ANCA, and neutrophils are both the target of ANCA and mediators of endothelial injury. NETs in particular have been shown to mediate tissue damage but also could be involved in the loss of tolerance to ANCA. Advances in understanding the role of the alternative pathway of the complement system in AAV have led to clinical trials of novel therapeutic agents. Further understanding of the mechanisms of disease may lead to the use of other novel therapeutics such as molecules to block NETosis, BLyS inhibitors, or monoclonal antibodies against IL-17 or IL-23.

\section{Competing interests}

The authors declare that they have no competing interests.

\section{Grant information}

We acknowledge support from the NIHR Imperial Biomedical Research Centre.

The funders had no role in study design, data collection and analysis, decision to publish, or preparation of the manuscript.
1. Stilmant MM, Bolton WK, Sturgill BC, et al.: Crescentic glomerulonephritis without immune deposits: clinicopathologic features. Kidney Int. 1979; 15(2): 184-95.

PubMed Abstract | Publisher Full Text

2. Davies DJ, Moran JE, Niall JF, et al:: Segmental necrotising glomerulonephritis with antineutrophil antibody: possible arbovirus aetiology? Br Med J (Clin Res Ed). 1982; 285(6342): 606

PubMed Abstract | Publisher Full Text | Free Full Text

3. Falk RJ, Jennette JC: Anti-neutrophil cytoplasmic autoantibodies with specificity for myeloperoxidase in patients with systemic vasculitis and idiopathic necrotizing and crescentic glomerulonephritis. N Engl J Med. 1988; 318(25): 1651-7.

PubMed Abstract | Publisher Full Text

4. Niles JL, McCluskey RT, Ahmad MF, et al.: Wegener's granulomatosis autoantigen is a novel neutrophil serine proteinase. Blood. 1989; 74(6): 1888-93. PubMed Abstract

5. van der Woude FJ, Rasmussen N, Lobatto S, et al.: Autoantibodies against neutrophils and monocytes: tool for diagnosis and marker of disease activity in Wegener's granulomatosis. Lancet. 1985; 1(8426): 425-9. PubMed Abstract | Publisher Full Text

6. Eisenberger U, Fakhouri F, Vanhille $P$, et al.: ANCA-negative pauci-immune rena vasculitis: histology and outcome. Nephrol Dial Transplant. 2005; 20(7): 1392-9. PubMed Abstract | Publisher Full Text

7. Watts RA, Lane SE, Bentham G, et al.: Epidemiology of systemic vasculitis: a ten-year study in the United Kingdom. Arthritis Rheum. 2000; 43(2): 414-9. PubMed Abstract | Publisher Full Text

8. Gonzalez-Gay MA, Garcia-Porrua C, Guerrero J, et al.: The epidemiology of the primary systemic vasculitides in northwest Spain: implications of the Chapel Hill Consensus Conference definitions. Arthritis Rheum. 2003; 49(3): 388-93. PubMed Abstract | Publisher Full Text

9. Mohammad AJ, Jacobsson LT, Westman KW, et al.: Incidence and survival rates in Wegener's granulomatosis, microscopic polyangiitis, Churg-Strauss syndrome and polyarteritis nodosa. Rheumatology (Oxford). 2009; 48(12): $1560-5$.

PubMed Abstract | Publisher Full Text

10. Fujimoto S, Watts RA, Kobayashi S, et al:: Comparison of the epidemiology of anti-neutrophil cytoplasmic antibody-associated vasculitis between Japan and the U.K. Rheumatology (Oxford). 2011; 50(10): 1916-20. PubMed Abstract | Publisher Full Text

11. F Lyons PA, Rayner TF, Trivedi S, et al:: Genetically distinct subsets within ANCA-associated vasculitis. N Engl J Med. 2012; 367(3): 214-23. PubMed Abstract | Publisher Full Text | Free Full Text | F1000 Recommendation

12. $F$ Merkel PA, Xie G, Monach PA, et al: Identification of Functional and Expression Polymorphisms Associated With Risk for Antineutrophil Cytoplasmic Autoantibody-Associated Vasculitis. Arthritis Rheumatol. 2017; 69(5): 1054-66.

PubMed Abstract | Publisher Full Text | Free Full Text | F1000 Recommendation

13. Cao Y, Schmitz JL, Yang J, et al.: DRB1*15 allele is a risk factor for PR3-ANCA disease in African Americans. J Am Soc Nephrol. 2011; 22(6): 1161-7. PubMed Abstract | Publisher Full Text | Free Full Text

14. Hilhorst $M$, Arndt $F$, Joseph Kemna $M$, et al:: HLA-DPB1 as a Risk Factor for Relapse in Antineutrophil Cytoplasmic Antibody-Associated Vasculitis: A Cohort Study. Arthritis Rheumatol. 2016; 68(7): 1721-30. PubMed Abstract | Publisher Full Text

15. Carr EJ, Niederer HA, Williams J, et al:: Confirmation of the genetic association of CTLA4 and PTPN22 with ANCA-associated vasculitis. BMC Med Genet. 2009;
10: 121.

PubMed Abstract | Publisher Full Text | Free Full Text

16. Martorana D, Maritati F, Malerba G, et al:: PTPN22 R620W polymorphism in the ANCA-associated vasculitides. Rheumatology (Oxford). 2012; 51(5): 805-12. PubMed Abstract | Publisher Full Text

17. Popa ER, Stegeman CA, Abdulahad WH, et al.: Staphylococcal toxicshock-syndrome-toxin-1 as a risk factor for disease relapse in Wegener's granulomatosis. Rheumatology (Oxford). 2007; 46(6): 1029-33. PubMed Abstract | Publisher Full Text

18. $\mathrm{F}$ Kain $\mathrm{R}$, Exner M, Brandes $\mathrm{R}$, et al.: Molecular mimicry in pauci-immune focal necrotizing glomerulonephritis. Nat Med. 2008; 14(10): 1088-96. PubMed Abstract | Publisher Full Text | Free Full Text | F1000 Recommendation

19. Roth AJ, Brown MC, Smith RN, et al:: Anti-LAMP-2 antibodies are not prevalent in patients with antineutrophil cytoplasmic autoantibody glomerulonephritis. $J$ Am Soc Nephrol. 2012; 23(3): 545-55 PubMed Abstract | Publisher Full Text | Free Full Text

20. F Peschel A, Basu N, Benharkou A, et al:: Autoantibodies to hLAMP-2 in ANCA-negative pauci-immune focal necrotizing GN. J Am Soc Nephrol. 2014; 25(3): 455-63.

PubMed Abstract | Publisher Full Text | Free Full Text | F1000 Recommendation

21. Pendergraft WF 3rd, Preston GA, Shah RR, et al.: Autoimmunity is triggered by cPR-3(105-201), a protein complementary to human autoantigen proteinase-3. Nat Med. 2004; 10(1): 72-9.

PubMed Abstract | Publisher Full Text

22. Pendergraft WF 3rd, Herlitz LC, Thornley-Brown D, et al:: Nephrotoxic effects of common and emerging drugs of abuse. Clin J Am Soc Nephrol. 2014; 9(11): 1996-2005.

PubMed Abstract | Publisher Full Text | Free Full Text

23. de Lind van Wijngaarden RA, van Rijn L, Hagen EC, et al.: Hypotheses on the etiology of antineutrophil cytoplasmic autoantibody associated vasculitis: the cause is hidden, but the result is known. Clin J Am Soc Nephrol. 2008; 3(1) 237-52.

PubMed Abstract | Publisher Full Text

24. Yu F, Chen M, Gao Y, et al:: Clinical and pathological features of renal involvement in propylthiouracil-associated ANCA-positive vasculitis. Am J Kidney Dis. 2007; 49(5): 607-14.

PubMed Abstract | Publisher Full Text

25. Bansal PJ, Tobin MC: Neonatal microscopic polyangiitis secondary to transfe of maternal myeloperoxidase-antineutrophil cytoplasmic antibody resulting in neonatal pulmonary hemorrhage and renal involvement. Ann Allergy Asthma Immunol. 2004; 93(4): 398-401.

PubMed Abstract | Publisher Full Text

26. F Fussner LA, Hummel AM, Schroeder DR, et al:: Factors Determining the Clinical Utility of Serial Measurements of Antineutrophil Cytoplasmic Antibodies Targeting Proteinase 3. Arthritis Rheumatol. 2016; 68(7): 1700-10. PubMed Abstract | Publisher Full Text | F1000 Recommendation

27. F Jayne DR, Gaskin G, Rasmussen N, et al:: Randomized trial of plasma exchange or high-dosage methylprednisolone as adjunctive therapy for severe renal vasculitis. J Am Soc Nephrol. 2007; 18(7): 2180-8. PubMed Abstract | Publisher Full Text | F1000 Recommendation

28. F Jones RB, Tervaert JW, Hauser T, et al.: Rituximab versus cyclophosphamide in ANCA-associated renal vasculitis. N Engl J Med. 2010; 363(3): 211-20.

PubMed Abstract | Publisher Full Text | F1000 Recommendation

29. F Stone JH, Merkel PA, Spiera R, et al:: Rituximab versus cyclophosphamide 
for ANCA-associated vasculitis. N Engl J Med. 2010; 363(3): 221-32. PubMed Abstract | Publisher Full Text | Free Full Text | F1000 Recommendation

30. F Guillevin L, Pagnoux C, Karras A, et al:: Rituximab versus azathioprine for maintenance in ANCA-associated vasculitis. N Engl J Med. 2014; 371(19): 1771-80.

PubMed Abstract | Publisher Full Text | F1000 Recommendation

31. Xiao H, Heeringa $\mathrm{P}, \mathrm{Hu} \mathrm{P}$, et al:: Antineutrophil cytoplasmic autoantibodies specific for myeloperoxidase cause glomerulonephritis and vasculitis in mice. J Clin Invest. 2002; 110(7): 955-63.

PubMed Abstract | Publisher Full Text | Free Full Text

32. Xiao $\mathrm{H}$, Heeringa $\mathrm{P}$, Liu $\mathrm{Z}$, et al.: The role of neutrophils in the induction of glomerulonephritis by anti-myeloperoxidase antibodies. Am J Pathol. 2005; 167(1): 39-45.

PubMed Abstract | Publisher Full Text | Free Full Text

33. Little MA, Smyth CL, Yadav R, et al:: Antineutrophil cytoplasm antibodies directed against myeloperoxidase augment leukocyte-microvascular interactions in vivo. Blood. 2005; 106(6): 2050-8.

PubMed Abstract | Publisher Full Text

34. Pfister $\mathrm{H}$, Ollert M, Fröhlich LF, et al: Antineutrophil cytoplasmic autoantibodies against the murine homolog of proteinase 3 (Wegener autoantigen) are pathogenic in vivo. Blood. 2004; 104(5): 1411-8.

PubMed Abstract | Publisher Full Text

35. Little MA: L7. Animal models of PR3-ANCA vasculitis: approaches and controversies. Presse Med. 2013; 42 (4 Pt 2): 512-5.

PubMed Abstract | Publisher Full Text

36. Xu PC, Cui Z, Chen M, et al:: Comparison of characteristics of natural autoantibodies against myeloperoxidase and anti-myeloperoxidase autoantibodies from patients with microscopic polyangiitis. Rheumatology (Oxford). 2011; 50(7): 1236-43.

PubMed Abstract | Publisher Full Tex

37. Nowack R, Grab I, Flores-Suarèz LF, et al:: ANCA titres, even of IgG subclasses, and soluble CD14 fail to predict relapses in patients with ANCA-associated vasculitis. Nephrol Dial Transplant. 2001; 16(8): 1631-7.

PubMed Abstract | Publisher Full Text

38. Mulder $\mathrm{AH}$, Heeringa $\mathrm{P}$, Brouwer $\mathrm{E}$, et al:: Activation of granulocytes by antineutrophil cytoplasmic antibodies (ANCA): a Fc gamma RII-dependent process. Clin Exp Immunol. 1994; 98(2): 270-8.

PubMed Abstract | Publisher Full Text | Free Full Text

39. F Roth AJ, Ooi JD, Hess JJ, et al.: Epitope specificity determines pathogenicity and detectability in ANCA-associated vasculitis. $J$ Clin Invest. 2013; 123(4): 1773-83.

PubMed Abstract | Publisher Full Text | Free Full Text | F1000 Recommendation

40. Falk RJ, Terrell RS, Charles LA, et al: Anti-neutrophil cytoplasmic autoantibodies induce neutrophils to degranulate and produce oxygen radicals in vitro. Proc Natl Acad Sci U S A. 1990; 87(11): 4115-9. PubMed Abstract | Publisher Full Text | Free Full Text

41. Savage CO, Gaskin G, Pusey CD, et al:: Anti-neutrophil cytoplasm antibodies can recognize vascular endothelial cell-bound anti-neutrophil cytoplasm antibody-associated autoantigens. Exp Nephrol. 1993; 1(3): 190-5. PubMed Abstract

42. Schreiber A, Xiao H, Jennette JC, et al:: C5a receptor mediates neutrophil activation and ANCA-induced glomerulonephritis. J Am Soc Nephrol. 2009; 20(2): 289-98.

PubMed Abstract | Publisher Full Text | Free Full Text

43. Radford DJ, Luu NT, Hewins P, et al:: Antineutrophil cytoplasmic antibodies stabilize adhesion and promote migration of flowing neutrophils on endothelial cells. Arthritis Rheum. 2001; 44(12): 2851-61. PubMed Abstract | Publisher Full Text

44. F Fuchs TA, Abed U, Goosmann C, et al: Novel cell death program leads to neutrophil extracellular traps. J Cell Biol. 2007; 176(2): 231-41. PubMed Abstract | Publisher Full Text | Free Full Text | F1000 Recommendation

45. Kessenbrock K, Krumbholz M, Schönermarck U, et al:: Netting neutrophils in autoimmune small-vessel vasculitis. Nat Med. 2009; 15(6): 623-5. PubMed Abstract | Publisher Full Text | Free Full Text

46. Villanueva E, Yalavarthi S, Berthier CC, et al:: Netting neutrophils induce endothelial damage, infiltrate tissues, and expose immunostimulatory molecules in systemic lupus erythematosus. J Immunol. 2011; 187(1): 538-52. PubMed Abstract | Publisher Full Text | Free Full Text

47. $\mathrm{F}$ Wang $\mathrm{H}$, Wang $\mathrm{C}$, Zhao $\mathrm{MH}$, et al:: Neutrophil extracellular traps can activate alternative complement pathways. Clin Exp Immunol. 2015; 181(3): $518-27$.

PubMed Abstract | Publisher Full Text | Free Full Text | F1000 Recommendation

48. Sangaletti $\mathrm{S}$, Tripodo C, Chiodoni C, et al.: Neutrophil extracellular traps mediate transfer of cytoplasmic neutrophil antigens to myeloid dendritic cells toward ANCA induction and associated autoimmunity. Blood. 2012; 120(15): 3007-18. PubMed Abstract | Publisher Full Text

49. Kettritz R, Jennette JC, Falk RJ: Crosslinking of ANCA-antigens stimulates superoxide release by human neutrophils. J Am Soc Nephrol. 1997; 8(3): 386-94. PubMed Abstract

50. Weidner S, Neupert W, Goppelt-Struebe M, et al:: Antineutrophil cytoplasmic antibodies induce human monocytes to produce oxygen radicals in vitro. Arthritis Rheum. 2001; 44(7): 1698-706. PubMed Abstract | Publisher Full Text
51. Jennette JC, Falk RJ: ANCAs are also antimonocyte cytoplasmic autoantibodies. Clin J Am Soc Nephrol. 2015; 10(1): 4-6. PubMed Abstract | Publisher Full Text | Free Full Text

52. Tarzi RM, Liu J, Schneiter S, et al: CD14 expression is increased on monocytes in patients with anti-neutrophil cytoplasm antibody (ANCA)-associated vasculitis and correlates with the expression of ANCA autoantigens. Clin Exp Immunol. 2015; 181(1): 65-75

PubMed Abstract | Publisher Full Text | Free Full Text

53. Haller $\mathrm{H}$, Eichhorn $\mathrm{J}$, Pieper $\mathrm{K}$, et al.: Circulating leukocyte integrin expression in Wegener's granulomatosis. J Am Soc Nephrol. 1996; 7(1): 40-8. PubMed Abstract

54. Weidner S, Carl M, Riess R, et al.: Histologic analysis of renal leukocyte infiltration in antineutrophil cytoplasmic antibody-associated vasculitis: importance of monocyte and neutrophil infiltration in tissue damage. Arthritis Rheum. 2004; 50(11): 3651-7. PubMed Abstract | Publisher Full Text

55. $\mathrm{F}$ Zhao L, David MZ, Hyjek E, et al:: M2 macrophage infiltrates in the early stages of ANCA-associated pauci-immune necrotizing GN. Clin J Am Soc Nephrol. 2015; 10(1): 54-62.

PubMed Abstract | Publisher Full Text | Free Full Text | F1000 Recommendation

56. F Rousselle A, Kettritz R, Schreiber A: Monocytes Promote Crescent Formation in Anti-Myeloperoxidase Antibody-Induced Glomerulonephritis. Am J Pathol. 2017; 187(9): 1908-15.

PubMed Abstract | Publisher Full Text | F1000 Recommendation

57. Xiao H, Schreiber A, Heeringa $\mathrm{P}$, et al:: Alternative complement pathway in the pathogenesis of disease mediated by anti-neutrophil cytoplasmic autoantibodies. Am J Pathol. 2007; 170(1): 52-64.

PubMed Abstract | Publisher Full Text | Free Full Text

58. F Huugen D, van Esch A, Xiao H, et al:: Inhibition of complement factor C5 protects against anti-myeloperoxidase antibody-mediated glomerulonephritis in mice. Kidney Int. 2007; 71(7): 646-54.

PubMed Abstract | Publisher Full Text | F1000 Recommendation

59. $\quad \mathrm{F}$ Xiao H, Dairaghi DJ, Powers JP, et al.: C5a receptor (CD88) blockade protects against MPO-ANCA GN. J Am Soc Nephrol. 2014; 25(2): 225-31. PubMed Abstract | Publisher Full Text | Free Full Text | F1000 Recommendation

60. Hao J, Wang C, Yuan J, et al:: A pro-inflammatory role of C5L2 in C5a-primed neutrophils for ANCA-induced activation. PLoS One. 2013; 8(6): e66305. PubMed Abstract | Publisher Full Text | Free Full Text

61. Xing GQ, Chen M, Liu G, et al:: Complement activation is involved in renal damage in human antineutrophil cytoplasmic autoantibody associated pauciimmune vasculitis. J Clin Immunol. 2009; 29(3): 282-91. PubMed Abstract | Publisher Full Text

62. Gou SJ, Yuan J, Wang C, et al.: Alternative complement pathway activation products in urine and kidneys of patients with ANCA-associated GN. Clin J Am Soc Nephrol. 2013; 8(11): 1884-91. PubMed Abstract | Publisher Full Text | Free Full Text

63. F Manenti L, Vaglio A, Gnappi E, et al:: Association of Serum C3 Concentration and Histologic Signs of Thrombotic Microangiopathy with Outcomes among Patients with ANCA-Associated Renal Vasculitis. Clin J Am Soc Nephrol. 2015; 10(12): 2143-51.

PubMed Abstract | Publisher Full Text | Free Full Text | F1000 Recommendation

64. Augusto JF, Langs V, Demiselle J, et al:: Low Serum Complement C3 Levels at Diagnosis of Renal ANCA-Associated Vasculitis Is Associated with Poor Prognosis. PLoS One. 2016; 11(7): e0158871. PubMed Abstract | Publisher Full Text | Free Full Text

65. Manenti L, Urban ML, Maritati F, et al.: Complement blockade in ANCAassociated vasculitis: an index case, current concepts and future perspectives. Intern Emerg Med. 2017; 12(6): 727-31. PubMed Abstract | Publisher Full Text

66. F Jayne DRW, Bruchfeld AN, Harper L, et al.: Randomized Trial of C5a Receptor Inhibitor Avacopan in ANCA-Associated Vasculitis. J Am Soc Nephrol. 2017; 28(9): 2756-67.

PubMed Abstract | Publisher Full Text | Free Full Text | F1000 Recommendation

67. Popa ER, Stegeman CA, Bos NA, et al.: Differential B- and T-cell activation in Wegener's granulomatosis. J Allergy Clin Immunol. 1999; 103(5 Pt 1): 885-94. PubMed Abstract | Publisher Full Text

68. F Alberici F, Smith RM, Jones RB, et al.: Long-term follow-up of patients who received repeat-dose rituximab as maintenance therapy for ANCA-associated vasculitis. Rheumatology (Oxford). 2015; 54(7): 1153-60.

PubMed Abstract | Publisher Full Text | Free Full Text | F1000 Recommendation

69. McAdoo SP, Medjeral-Thomas N, Gopaluni S, et al:: Long-term follow-up of a combined rituximab and cyclophosphamide regimen in renal anti-neutrophil cytoplasm antibody-associated vasculitis. Nephrol Dial Transplant. 2018. PubMed Abstract | Publisher Full Text

70. $\mathrm{F}$ Bunch DO, Mendoza CE, Aybar LT, et al.: Gleaning relapse risk from $\mathrm{B}$ cell phenotype: decreased $C D 5^{+} B$ cells portend a shorter time to relapse after $B$ cell depletion in patients with ANCA-associated vasculitis. Ann Rheum Dis. 2015; 74(9): 1784-6.

PubMed Abstract | Publisher Full Text | Free Full Text | F1000 Recommendation

71. Culton DA, Nicholas MW, Bunch DO, et al.: Similar CD19 dysregulation in two autoantibody-associated autoimmune diseases suggests a shared mechanism 
of B-cell tolerance loss. J Clin Immunol. 2007; 27(1): 53-68. PubMed Abstract | Publisher Full Text

72. F Jennette JC, Falk RJ: B cell-mediated pathogenesis of ANCA-mediated vasculitis. Semin Immunopathol. 2014; 36(3): 327-38. PubMed Abstract | Publisher Full Text | Free Full Text | F1000 Recommendation

73. Todd SK, Pepper RJ, Draibe J, et al.: Regulatory B cells are numerically but not functionally deficient in anti-neutrophil cytoplasm antibody-associated vasculitis. Rheumatology (Oxford). 2014; 53(9): 1693-703. PubMed Abstract | Publisher Full Text | Free Full Text

74. Wilde B, Thewissen M, Damoiseaux J, et al:: Regulatory B cells in ANCAassociated vasculitis. Ann Rheum Dis. 2013; 72(8): 1416-9. PubMed Abstract | Publisher Full Text

75. F Holden NJ, Williams JM, Morgan MD, et al:: ANCA-stimulated neutrophils release BLyS and promote $B$ cell survival: a clinically relevant cellular process. Ann Rheum Dis. 2011; 70(12): 2229-33. PubMed Abstract | Publisher Full Text | F1000 Recommendation

76. Sanders JS, Huitma MG, Kallenberg CG, et al:: Plasma levels of soluble interleukin 2 receptor, soluble $\mathrm{CD} 30$, interleukin 10 and $B$ cell activator of the tumour necrosis factor family during follow-up in vasculitis associated with proteinase 3-antineutrophil cytoplasmic antibodies: associations with disease activity and relapse. Ann Rheum Dis. 2006; 65(11): 1484-9. PubMed Abstract | Publisher Full Text | Free Full Text

77. Krumbholz M, Specks $U$, Wick M, et al:: BAFF is elevated in serum of patients with Wegener's granulomatosis. J Autoimmun. 2005; 25(4): 298-302. PubMed Abstract | Publisher Full Text

78. Pollard RP, Abdulahad WH, Vissink A, et al:: Serum levels of BAFF, but not APRIL, are increased after rituximab treatment in patients with primary Sjogren's syndrome: data from a placebo-controlled clinical trial. Ann Rheum Dis. 2013; 72(1): 146-8. PubMed Abstract | Publisher Full Text

79. F Alberici F, Smith RM, Fonseca M, et al.: Association of a TNFSF13B (BAFF) regulatory region single nucleotide polymorphism with response to rituximab in antineutrophil cytoplasmic antibody-associated vasculitis. J Allergy Clin Immunol. 2017; 139(5): 1684-1687.e10.

PubMed Abstract | Publisher Full Text | F1000 Recommendation

80. Jayne D, Blockmans D, Luqmani R, et al:: Efficacy and Safety of Belimumab in Combination with Azathioprine for Remission Maintenance in Granulomatosis with Polyangiitis and Microscopic Polyangiitis: A Multicenter Randomized, Placebo-Controlled Study (abstract). Arthritis Rheumatol. 2017; 69(suppl 10). Reference Source

81. Morgan MD, Day CJ, Piper KP, et al.: Patients with Wegener's granulomatosis demonstrate a relative deficiency and functional impairment of T-regulatory cells. Immunology. 2010; 130(1): 64-73.

PubMed Abstract | Publisher Full Text | Free Full Text

82. Free ME, Bunch DO, McGregor JA, et al:: Patients with antineutrophil cytoplasmic antibody-associated vasculitis have defective Treg cell function exacerbated by the presence of a suppression-resistant effector cel population. Arthritis Rheum. 2013; 65(7): 1922-33. PubMed Abstract | Publisher Full Text | Free Full Text

83. Schmitt WH, Hagen EC, Neumann I, et al:: Treatment of refractory Wegener's granulomatosis with antithymocyte globulin (ATG): an open study in 15 patients. Kidney Int. 2004; 65(4): 1440-8. PubMed Abstract | Publisher Full Tex
84. Schönermarck $U$, Csernok E, Trabandt A, et al.: Circulating cytokines and soluble CD23, CD26 and CD30 in ANCA-associated vasculitides. Clin Exp Rheumatol. 2000; 18(4): 457-63.

PubMed Abstract

85. Gan PY, Holdsworth SR, Kitching AR, et al:: Myeloperoxidase (MPO)-specific $\mathrm{CD}^{+} \mathrm{T}$ cells contribute to MPO-anti-neutrophil cytoplasmic antibody (ANCA) associated glomerulonephritis. Cell Immunol. 2013; 282(1): 21-7. PubMed Abstract | Publisher Full Text

86. Ruth A, Kitching AR, Kwan RY, et al:: Anti-neutrophil cytoplasmic antibodies and effector $\mathrm{CD}^{+}$cells play nonredundant roles in anti-myeloperoxidase crescentic glomerulonephritis. J Am Soc Nephrol. 2006; 17(7): 1940-9.

PubMed Abstract | Publisher Full Text

87. F Chang J, Eggenhuizen P, O'Sullivan KM, et al:: CD8+ T Cells Effect Glomerular Injury in Experimental Anti-Myeloperoxidase GN. J Am Soc Nephrol. 2017; 28(1): 47-55.

PubMed Abstract | Publisher Full Text | Free Full Text | F1000 Recommendation

88. Ooi JD, Chang J, Hickey MJ, et al.: The immunodominant myeloperoxidase T-cell epitope induces local cell-mediated injury in antimyeloperoxidase glomerulonephritis. Proc Natl Acad Sci U S A. 2012; 109(39): E2615-24. PubMed Abstract | Publisher Full Text | Free Full Text

89. Nogueira E, Hamour S, Sawant D, et al.: Serum IL-17 and IL-23 levels and autoantigen-specific Th17 cells are elevated in patients with ANCA-associated vasculitis. Nephrol Dial Transplant. 2010; 25(7): 2209-17. PubMed Abstract | Publisher Full Text

90. Hoshino A, Nagao T, Nagi-Miura N, et al.: MPO-ANCA induces IL-17 production by activated neutrophils in vitro via classical complement pathway-dependent manner. J Autoimmun. 2008; 31(1): 79-89.

PubMed Abstract | Publisher Full Text

91. Gan PY, Steinmetz OM, Tan DS, et al:: Th17 cells promote autoimmune antimyeloperoxidase glomerulonephritis. J Am Soc Nephrol. 2010; 21(6): 925-31.

PubMed Abstract | Publisher Full Text | Free Full Text

92. Mueller A, Holl-Ulrich K, Gross WL: Granuloma in ANCA-associated vasculitides: another reason to distinguish between syndromes? Curr Rheumatol Rep. 2013; 15(11): 376

PubMed Abstract | Publisher Full Text

93. Schönermarck U, Csernok E, Gross WL: Pathogenesis of anti-neutrophil cytoplasmic antibody-associated vasculitis: challenges and solutions 2014. Nephrol Dial Transplant. 2015; 30 Suppl 1: i46-52.

PubMed Abstract | Publisher Full Tex

94. Csernok E, Trabandt A, Müller A, et al.: Cytokine profiles in Wegener's granulomatosis: predominance of type 1 (Th1) in the granulomatous inflammation. Arthritis Rheum. 1999; 42(4): 742-50. PubMed Abstract | Publisher Full Text

95. Zhao Y, Odell E, Choong LM, et al:: Granulomatosis with polyangiitis involves sustained mucosal inflammation that is rich in B-cell survival factors and autoantigen. Rheumatology (Oxford). 2012; 51(9): 1580-6. PubMed Abstract | Publisher Full Text

96. Kesel N, Köhler D, Herich L, et al:: Cartilage destruction in granulomatosis with polyangiitis (Wegener's granulomatosis) is mediated by human fibroblasts after transplantation into immunodeficient mice. Am J Pathol. 2012; 180(5): 2144-55.

PubMed Abstract | Publisher Full Tex 


\section{Open Peer Review}

\section{Current Peer Review Status:}

\section{Editorial Note on the Review Process}

Faculty Reviews are review articles written by the prestigious Members of Faculty Opinions. The articles are commissioned and peer reviewed before publication to ensure that the final, published version is comprehensive and accessible. The reviewers who approved the final version are listed with their names and affiliations.

\section{The reviewers who approved this article are:}

\section{Version 1}

\section{Augusto Vaglio}

Nephrology Unit, University Hospital of Parma, Parma, Italy

Competing Interests: No competing interests were disclosed.

\section{Minghui Zhao} Institute of Nephrology, Peking University First Hospital, Beijing, China

Competing Interests: No competing interests were disclosed.

The benefits of publishing with F1000Research:

- Your article is published within days, with no editorial bias

- You can publish traditional articles, null/negative results, case reports, data notes and more

- The peer review process is transparent and collaborative

- Your article is indexed in PubMed after passing peer review

- Dedicated customer support at every stage

For pre-submission enquiries, contact research@f1000.com 